\title{
Modelling the dynamic response of a solid oxide steam electrolyser to transient inputs during renewable hydrogen production
}

(C) Higher Education Press and Springer-Verlag Berlin Heidelberg 2010

\begin{abstract}
Hydrogen is regarded as a leading candidate for alternative future fuels. Solid oxide electrolyser cells (SOEC) may provide a cost-effective and green route to hydrogen production especially when coupled to a source of renewable electrical energy. Developing an understanding of the response of the SOEC stack to transient events that may occur during its operation with intermittent electricity input is essential before the realisation of this technology. In this paper, a one-dimensional (1D) dynamic model of a planar SOEC stack has been employed to study the dynamic behaviour of such an SOEC and the prospect for stack temperature control through variation of the air flow rate. Step changes in the average current density from 1.0 to $0.75,0.5$ and $0.2 \mathrm{~A} / \mathrm{cm}^{2}$ have been imposed on the stacks, replicating the situation in which changes in the supply of input electrical energy are experienced, or the sudden switch-off of the stack. Such simulations have been performed both for open-loop and closed-loop cases. The stack temperature and cell voltage are decreased by step changes in the average current density. Without temperature control via variation of the air flow rate, a sudden fall of the temperature and the cell potential occurs during all the step changes in average current density. The temperature excursions between the initial and final steady states are observed to be reduced by the manipulation of the air flow rate. Provided that the change in the average current density does not result in a transition from exothermic to endothermic operation of the SOEC, the use of the air flow
\end{abstract}

Received March 21, 2010; accepted May 5, 2010

Qiong CAI ( $($ ) , Nigel P. BRANDON

Department of Earth Science and Engineering, Imperial College London, London SW7 2AZ, UK

E-mail: q.cai@imperial.ac.uk

Claire S. ADJIMAN

Department of Chemical Engineering, Centre for Process Systems Engineering, Imperial College London, London SW7 2AZ, UK rate to maintain a constant steady-state temperature is found to be successful.

Keywords hydrogen production, renewable energy, solid oxide electrolyser cell, 1D dynamic model, dynamic behaviour, temperature control

\section{Introduction}

Hydrogen is regarded as a leading candidate for alternative future fuels. It has the potential to address the environmental and energy security issues associated with fossilderived hydrocarbon fuels. Among many hydrogen production methods, water electrolysis is a well-established technique which, however, has not had a significant commercial penetration, mainly due to its high electricity consumption and related high operating cost $[1,2]$. High temperature electrolysis is a promising alternative to the conventional lower temperature water electrolysis process. A combination of favourable thermodynamics and kinetics at high temperatures $\left(500-1000^{\circ} \mathrm{C}\right)$ offers reduced electrical energy consumption per unit of hydrogen compared to low temperature water electrolysis, and thus may provide a cost-effective route to hydrogen production. This approach is particularly advantageous if a high temperature electrolyser may be simply and efficiently coupled to a source of renewable solar [3,4], geothermal $[5,6]$, wind [4] or nuclear [7] electrical energies, to produce carbon-free hydrogen.

High temperature electrolysis is performed using a solid oxide electrolysis cell (SOEC), which can be seen in simple terms as the reverse operation of a solid oxide fuel cell (SOFC). An SOEC consists of a three-layer solid structure (composed of porous cathode, electrolyte and porous anode) and an interconnect plate. Steam is introduced at the cathode side of the solid structure where it is reduced into hydrogen, releasing oxide ions in 
1 the process. The oxide ions then migrate through the electrolyte to the anode where they combine to form oxygen molecules, releasing electrons. A number of repeating cells are normally packed into a stack to achieve 5 a sufficient hydrogen production rate. During the operation of an SOEC system, heat is generated in the stack as a result of irreversible losses. An SOEC stack can function in either exothermic, endothermic or thermoneutral operating modes. In the exothermic operation mode, the temperature

10 increases along the stack due to the heat accumulated from the irreversible losses. In the endothermic operation, the heat generated via irreversible losses is lower than the thermal energy consumed by the reaction, which results in a temperature decrease as the reaction proceeds along the

15 stack. Finally, thermoneutral stack operation occurs when the thermal energy consumed by the reaction is precisely matched by the heat generated via irreversible losses. A change in operating conditions (such as stack temperature, average current density, operating voltage, steam utilisa20 tion and the inlet gas composition) can alter the operating mode of the stack.

As in SOFCs, the most common electrolyte material used in SOECs is yttria-stabilized zirconia (YSZ) which exhibits high oxygen ion conductivity and good mechanical strength. Typical materials for the cathode are nickelYSZ cermets and those for the anode are perovskite oxides such as lanthanum strontium manganite (LSM). Ceramics like those used in SOECs are typically brittle materials exhibiting little plasticity and low fracture toughness, and

30 subjected to stresses that can arise from manufacturing (residual stresses), differences between thermal expansion coefficients, temperature gradients along the cell, oxygen activity gradients, and/or external mechanical loading. In general, a mixture of all these sources of stress is likely to

35 be present and their magnitude depends on the properties of the materials, operating conditions, and design. During the normal operation of a SOEC, the suppression of temperature gradients or transients that can cause excessive stresses within the SOEC components and lead to cell

40 breakdown is crucial. Such problem becomes more severe when the operation of the SOEC is integrated with intermittent energy sources. Due to their intermittent nature, renewable energy resources - such as wind and solar energies - cannot produce power steadily, since their

45 power production rates change with seasons, months, days, hours etc. Such variation in the electricity input may cause undesirable temperature fluctuations and significant thermal excursion within the SOEC stack. The operation of the SOEC should be guaranteed over an acceptable tempera50 ture range.

The development of an understanding of the response of the SOEC stack, especially its temperature profiles, to transient events that may occur during its operation with intermittent energy input is therefore essential before this technology can be deployed. The development of an appropriate control strategy over temperature fluctuations is also desirable.

To capture the spatially-distributed stack performance (especially the temperature distribution during operation) and the transient behaviour of a stack when integrated with intermittent energy resources, a one-dimensional distributed dynamic model of a cathode-supported planar SOEC stack has been developed, with which some preliminary investigations on the operation of SOECs have been report ed [8-10]. The model developed is employed here to predict the stack response during step changes in the average current density which might be caused by the timedependent nature of the supply of electrical energy to the SOEC or the demand for hydrogen from the SOEC.

\section{Description of the 1-D dynamic model}

To ensure a sufficient rate of $\mathrm{H}_{2}$ production, an SOEC system must consist of several repeating cells assembled in stacks. The models of such stacks are usually constructed for the smallest unit cell, which is assumed to describe the response of the whole stack subject to the use of adequate boundary conditions. Here, the modelled unit cell is considered to be in the centre of a sufficiently large stack that end effects are negligible. Although interconnects normally provide the gas flow channels above and below the solid structure, the effect of individual passages is neglected here. The pressure drop along the gas channels is also assumed negligible at the operating pressure of $0.1 \mathrm{MPa}$. For modelling purposes, the unit cell is considered to consist of four components, the cathode and the anode gas streams, the solid structure (which includes the two electrodes - cathode and anode, and electrolyte) and the interconnect. The schematic view of such a unit cell is shown in Fig. 1. The cathode stream inlet gas is composed of $\mathrm{H}_{2}$ and $\mathrm{H}_{2} \mathrm{O}$. The addition of hydrogen in the cathode stream avoids the oxidation of materials that

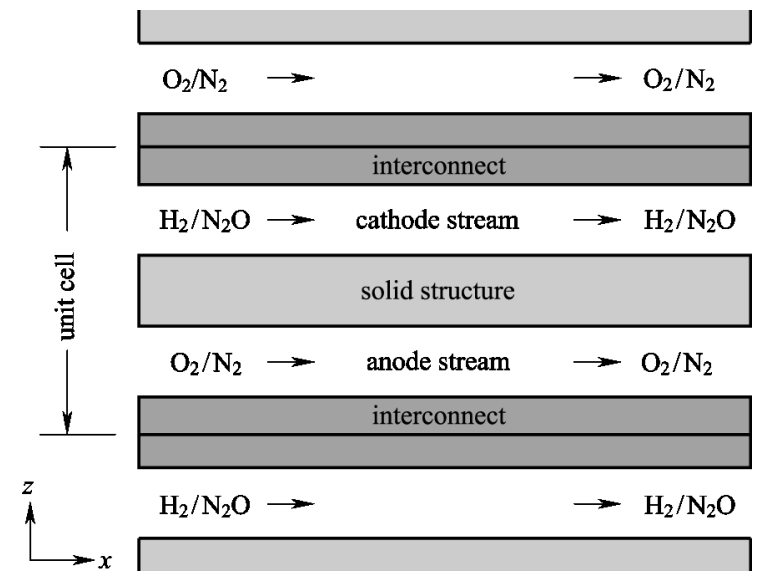

Fig. 1 Schematic view of a unit cell of a planar SOEC stack 
1 might be induced by using pure steam. Hydrogen can be circulated from that produced on the anode side. On the anode side, air is introduced to enable the temperature control of the stack; the air feed also permits the convective transport of the oxygen produced. The inlet air composition is assumed to be $21 \mathrm{~mol} \% \mathrm{O}_{2} / 79 \mathrm{~mol} \% \mathrm{~N}_{2}$.

The model developed consists of an electrochemical model, mass balances for the gas streams, and energy balances for the cathode and anode streams, solid structure and interconnect.

\subsection{Electrochemical model}

An electrochemical model is used to relate variables such as gas species concentrations, cell component temperatures and average current density to the electrical potential of the cell, which can then be used to calculate the electrical energy consumption. The electrical potential is taken as constant along the cell as the electrodes are assumed to be good electronic conductors. As shown in Eq. (1), the cell potential corresponds to the sum of the reversible potential and all the irreversible losses that occur as the electrical current is passed through the cell. Such irreversible losses include Ohmic losses, cathode and anode concentration overpotentials, and cathode and anode activation overpotentials, which are all partly responsible for the heat produced within the cell. The calculation of these irreversible losses can be found in Refs. [8,10]. For the work reported in this paper, a contact resistance of $0.1 \Omega$. $\mathrm{cm}^{2}$ between coating and interconnect has been taken into account for the irreversible losses in addition to those calculated in Refs. $[8,10]$.

$$
\begin{aligned}
U= & U^{\mathrm{rev}}(x)+\eta_{\mathrm{Ohm}}(x)+\eta_{\text {conc,cathode }}(x) \\
& +\eta_{\text {conc,anode }}(x)+\eta_{\text {act,cathode }}(x)+\eta_{\text {act,anode }}(x) \\
& +\eta_{\text {contact }} .
\end{aligned}
$$

The reversible potential is determined through the Nernst equation, which predicts the minimum electrical potential required to split $\mathrm{H}_{2} \mathrm{O}$ at a particular location along the cell with a specific temperature and gas concentrations. Equation (2) has been derived assuming ideal gas behaviour. The solid structure temperature is applied in the Nernst equation as the reactions take place at the triple phase boundaries (TPBs) where the electrolyte, porous electrode and gas species meet at the interfaces between the electrolyte and the electrodes. $U^{0}$ represents the standard potential, which corresponds to the reversible potential calculated at unity activity. It is determined as a function of the Gibbs free energy change involved in the reaction, taking the partial pressures of $\mathrm{H}_{2}, \mathrm{H}_{2} \mathrm{O}$ and $\mathrm{O}_{2}$ to be at standard pressure.

$$
\begin{aligned}
U^{\mathrm{rev}}(x)= & U^{0}(x) \\
& +\frac{\Re T_{\mathrm{S}}(x)}{2 F} \ln \left(\frac{C_{\mathrm{H}_{2}}(x)\left(P_{\mathrm{O}_{2}} \times 10^{-5}\right)^{0.5}}{C_{\mathrm{H}_{2} \mathrm{O}}(x)}\right) .
\end{aligned}
$$

Ohmic losses are linearly proportional to the current density and can be determined through Ohm's law as shown in Eq. (3), where $j$ and $R_{\mathrm{Ohm}}$ represent the local current density and local cell resistance, respectively. $R_{\mathrm{Ohm}}$ is calculated using the conductivity data of each layer of the solid structure. In Eq. (4), cross plane charge flow and series connection of resistances have been assumed. The conductivity of the electrodes is assumed constant along the cell while that of the electrolyte is estimated as a function of local temperature.

$$
\begin{gathered}
\eta_{\mathrm{Ohm}}(x)=j(x) R_{\mathrm{Ohm}}(x), \\
R_{\mathrm{Ohm}}(x)=\frac{\tau_{\text {cathode }}}{\sigma_{\text {cathode }}}+\frac{\tau_{\text {electrolyte }}}{\sigma_{\text {electrolyte }}(x)}+\frac{\tau_{\text {anode }}}{\sigma_{\text {anode }}} .
\end{gathered}
$$

Concentration gradients for the species develop in the porous electrode, if the fluxes of the reactant to, and the products away from, the TPBs are slower than that corresponding to the discharged electrical current. The cathode concentration overpotential is represented in Eq. (5). Equation (6) describes the anode concentration overpotential with air-fed anode channels. Note that the temperature of the gas mixture at the TPBs is represented by the solid structure temperature.

$$
\begin{gathered}
\eta_{\text {conc,cathode }}(x)=\frac{\Re T_{\mathrm{S}}(x)}{2 F} \ln \left(\frac{C_{\mathrm{H}_{2}}^{\mathrm{TPB}}(x) C_{\mathrm{H}_{2} \mathrm{O}}(x)}{C_{\mathrm{H}_{2}}(x) C_{\mathrm{H}_{2} \mathrm{O}}^{\mathrm{TPB}}(x)}\right), \\
\eta_{\text {conc,anode }}(x)=\frac{\Re T_{\mathrm{S}}(x)}{4 F} \ln \left(\frac{C_{\mathrm{O}_{2}}^{\mathrm{TPB}}(x) T_{\mathrm{S}}(x)}{C_{\mathrm{O}_{2}}(x) T_{\mathrm{A}}(x)}\right) .
\end{gathered}
$$

The diffusion activities of $\mathrm{H}_{2}$ and $\mathrm{H}_{2} \mathrm{O}$ in the porous cathode are expressed in Eqs. (7) and (8), whilst the diffusion activity of $\mathrm{O}_{2}$ in the porous anode is represented in Eq. (9), where $D_{\text {eff,cathode }}$ represents the average effective diffusivity coefficients in the cathode, considering a binary gas mixture of $\mathrm{H}_{2}$ and $\mathrm{H}_{2} \mathrm{O}$; and $D_{\text {eff,anode }}$ represents the average effective diffusivity coefficient in the anode, considering a binary gas mixture of $\mathrm{O}_{2}$ and $\mathrm{N}_{2}$.

$$
\begin{aligned}
& C_{\mathrm{H}_{2}}^{\mathrm{TPB}}(x)=C_{\mathrm{H}_{2}}(x)+\frac{\tau_{\text {cathode }}}{2 F D_{\text {eff,cathode }}} \cdot j(x), \\
& C_{\mathrm{H}_{2} \mathrm{O}}^{\mathrm{TPB}}(x)=C_{\mathrm{H}_{2} \mathrm{O}}(x)-\frac{\tau_{\text {cathode }}}{2 F D_{\text {eff,cathode }}} \cdot j(x),
\end{aligned}
$$




$$
C_{\mathrm{O}_{2}}^{\mathrm{TPB}}(x)=C_{\mathrm{O}_{2}}(x)+C_{\mathrm{N}_{2}}(x)-C_{\mathrm{N}_{2}}(x) \exp \left(\frac{-j(x) \tau_{\text {anode }}}{4 F D_{\text {eff, anode }}\left[C_{\mathrm{O}_{2}}(x)+C_{\mathrm{N}_{2}}(x)\right]}\right) .
$$

Activation overpotentials are classically determined through the Butler-Volmer equation. The extended form of the Butler-Volmer equation is applied to account for the differences in the gas concentrations at the TPBs and in the bulk stream. Equations (10) and (11) are for the cathode and anode activation overpotentials respectively. Although reactions are generally rapid and activation overpotentials tend to be small at high temperatures, they can become the most significant form of irreversible losses as the operating temperature is reduced.

$$
j(x)=j_{0, \text { cathode }}(x)\left[\frac{C_{\mathrm{H}_{2}}^{\mathrm{TPB}}(x)}{C_{\mathrm{H}_{2}}(x)} \exp \left(\frac{2(1-\alpha) F}{\Re T_{\mathrm{S}}(x)} \eta_{\text {act,cathode }}(x)\right)-\frac{C_{\mathrm{H}_{2} \mathrm{O}}^{\mathrm{TPB}}(x)}{C_{\mathrm{H}_{2} \mathrm{O}}(x)} \exp \left(\frac{-2 \alpha F}{\Re T_{\mathrm{S}}(x)} \eta_{\text {act,cathode }}(x)\right)\right],
$$

$$
j(x)=j_{0, \text { anode }}(x)\left[\exp \left(\frac{2(1-\alpha) F}{\Re T_{\mathrm{S}}(x)} \eta_{\text {act,anode }}(x)\right)-\frac{C_{\mathrm{O}_{2}}^{\mathrm{TPB}}(x)}{C_{\mathrm{O}_{2}}(x)} \exp \left(\frac{-2 \alpha F}{\Re T_{\mathrm{S}}(x)} \eta_{\text {act,anode }}(x)\right)\right],
$$

where $\alpha$ (usually taken to be 0.5 ), $j_{0 \text {,cathode }}$ and $j_{0 \text {,anode }}$ 20 represent the transfer coefficient and the exchange current density for the cathode and anode, respectively. Electrode exchange current densities are expressed in Eq. (12) as a function of the pre-exponential factor and activation energy. It is assumed that in an SOEC, the forward and 25 backward reactions at each electrode as well as the electrode materials are the reverse of those in an SOFC. Hence the values used for $k_{\text {anode }}$ and $E_{\text {anode }}$ in previous ISOFC studies [11] have been substituted into $k_{\text {anode }}$ and $E_{\text {anode }}$ in the IT-SOEC model. The same assumption is used

30 when assigning the values to the SOEC anode kinetic parameters. The parameters employed for the SOEC simulations are shown in Table 1.

$$
j_{0, \text { electrode }}(x)=\frac{\Re T_{\mathrm{S}}(x)}{2 F} k_{\text {electrode }} \exp \left(\frac{-E_{\text {electrode }}}{\Re T_{\mathrm{S}}(x)}\right),
$$

$$
\text { electrode } \in \text { \{cathode,anode }\} \text {. }
$$

\subsection{Mass balances}

The composition of the cathode stream evolves along the cell as the $\mathrm{H}_{2} / \mathrm{H}_{2} \mathrm{O}$ mixture moves towards the outlet. Such a composition change is tracked in the model using the cathode stream mass balance (as shown in Eqs. (13)(15)) predicting the $\mathrm{H}_{2}$ and $\mathrm{H}_{2} \mathrm{O}$ concentrations at each location along the channel [8]. The anode stream mass balance (as shown in Eqs. (16) and (17)) predicts the $\mathrm{O}_{2}$ and $\mathrm{N}_{2}$ concentrations at each location along the stack [10]. The cathode and anode stream velocities are assumed constant (i.e. negligible frictional pressure drops along the stack) and determined from the outlet flow rate of the streams.

$$
\begin{gathered}
\frac{\partial}{\partial t}\left[C_{i}(x)\right]=-u_{\mathrm{C}} \frac{\partial}{\partial x}\left[C_{i}(x)\right]+\frac{1}{h_{\mathrm{C}}} \nu_{i} R(x), i \\
\in\left\{\mathrm{H}_{2}, \mathrm{H}_{2} \mathrm{O}\right\}, \\
C_{i}(0)=C_{i}^{0}, i \in\left\{\mathrm{H}_{2}, \mathrm{H}_{2} \mathrm{O}\right\}, \\
R(x)=\frac{j(x)}{2 F}, \\
\frac{\partial}{\partial t}\left[C_{i}(x)\right]=-u_{\mathrm{A}} \frac{\partial}{\partial x}\left[C_{i}(x)\right]+\frac{1}{h_{\mathrm{A}}} \nu_{i} R(x), i \\
\in\left\{\mathrm{O}_{2}, \mathrm{~N}_{2}\right\}, \\
C_{i}(0)=C_{i}^{0}, i \in\left\{\mathrm{O}_{2}, \mathrm{~N}_{2}\right\} .
\end{gathered}
$$

\subsection{Energy balances}

In the energy balances, it is considered that the thermal fluxes between the gas streams and the solid parts of the cell are fully described by convection. The thermal fluxes along the solid parts of the cell are modelled using Fourier's law of heat conduction while radiative heat exchange is taken into account between the solid structure and the interconnect. The entire enthalpy change of the reaction is assumed to occur in the solid structure. Mean density and mean heat capacity values are applied in the anode and cathode energy balances. These are calculated as spatial averages of all the values along the cell. The

Table 1 Pre-exponential factor and activation energy for the exchange current density

\begin{tabular}{lccc}
\hline$k_{\text {cathode }} /\left(\Omega^{-1} \cdot \mathrm{m}^{-2}\right)$ & $k_{\text {anode }} /\left(\Omega^{-1} \cdot \mathrm{m}^{-2}\right)$ & $E_{\text {cathode }} /\left(\mathrm{J} \cdot \mathrm{mol}^{-1}\right)$ & $E_{\text {anode }} /\left(\mathrm{J} \cdot \mathrm{mol}^{-1}\right)$ \\
\hline $6.54 \times 10^{11}$ & $2.35 \times 10^{11}$ & $1.40 \times 10^{5}$ & $1.37 \times 10^{5}$ \\
\hline
\end{tabular}


remaining gas and material properties are taken to be constant along the cell. Equations (18)-(27) describe all the heat conduction mechanisms considered in this work.

$$
T_{\mathrm{C}}(0)=T_{\mathrm{C}}^{0}
$$

$$
\begin{aligned}
\frac{\partial}{\partial t}\left[T_{\mathrm{A}}(x)\right]= & -u_{\mathrm{A}} \frac{\partial}{\partial x}\left[T_{\mathrm{A}}(x)\right] \\
& +\frac{k_{\mathrm{A}}}{\rho_{\mathrm{A}} c_{\mathrm{p}, \mathrm{A}} h_{\mathrm{A}}}\left[T_{\mathrm{S}}(x)-T_{\mathrm{A}}(x)\right] \\
& +\frac{k_{\mathrm{A}}}{\rho_{\mathrm{A}} c_{\mathrm{p}, \mathrm{A}} h_{\mathrm{A}}}\left[T_{\mathrm{I}}(x)-T_{\mathrm{A}}(x)\right],
\end{aligned}
$$

$$
\frac{\partial}{\partial t}\left[T_{\mathrm{S}}(x)\right]=\frac{\lambda_{\mathrm{S}}}{\rho_{\mathrm{S}} c_{\mathrm{p}, \mathrm{S}}} \frac{\partial^{2}}{\partial x^{2}}\left[T_{\mathrm{S}}(x)\right]-\frac{k_{\mathrm{C}}}{\rho_{\mathrm{S}} c_{\mathrm{p}, \mathrm{S}} h_{\mathrm{S}}}\left[T_{\mathrm{S}}(x)-T_{\mathrm{C}}(x)\right]
$$$$
-\frac{k_{\mathrm{A}}}{\rho_{\mathrm{S}} c_{\mathrm{p}, \mathrm{S}} h_{\mathrm{S}}}\left[T_{\mathrm{S}}(x)-T_{\mathrm{A}}(x)\right]
$$$$
-\frac{2}{\rho_{\mathrm{S}} c_{\mathrm{p}, \mathrm{S}} h_{\mathrm{S}}}\left[\frac{\sigma\left[T_{\mathrm{S}}(x)^{4}-T_{\mathrm{I}}(x)^{4}\right]}{1 / \varepsilon_{\mathrm{S}}+1 / \varepsilon_{\mathrm{I}}-1}\right]
$$$$
+\frac{1}{\rho_{\mathrm{S}} c_{\mathrm{p}, \mathrm{S}} h_{\mathrm{S}}}[-\Delta H(x) R(x)+j(x) U]
$$

$$
\begin{aligned}
& \frac{\partial}{\partial x}\left[T_{S}(0)\right]=0, \quad \frac{\partial}{\partial x}\left[T_{S}(L)\right]=0 \\
& \frac{\partial}{\partial t}\left[T_{\mathrm{I}}(x)\right]= \frac{\lambda_{\mathrm{I}}}{\rho_{\mathrm{I}} c_{\mathrm{p}, \mathrm{I}}} \frac{\partial^{2}}{\partial x^{2}}\left[T_{\mathrm{I}}(x)\right]-\frac{k_{\mathrm{C}}}{\rho_{\mathrm{I}} c_{\mathrm{p}, \mathrm{I}} h_{\mathrm{I}}}\left[T_{\mathrm{I}}(x)-T_{\mathrm{C}}(x)\right] \\
&-\frac{k_{\mathrm{A}}}{\rho_{\mathrm{I}} c_{\mathrm{p}, \mathrm{I}} h_{\mathrm{I}}}\left[T_{\mathrm{I}}(x)-T_{\mathrm{A}}(x)\right] \\
&+\frac{2}{\rho_{\mathrm{I}} c_{\mathrm{p}, \mathrm{I}} h_{\mathrm{I}}}\left[\frac{\sigma\left[T_{\mathrm{S}}(x)^{4}-T_{\mathrm{I}}(x)^{4}\right]}{1 / \varepsilon_{\mathrm{S}}+1 / \varepsilon_{\mathrm{I}}-1}\right]
\end{aligned}
$$

el Builder 3.1.4. Parameters such as cell geometry, material properties, thermal properties and operating conditions need to be specified as model input. The model input parameters and operating conditions that are specified are shown in Table 2. The parameters in Table 1 reflect the cell geometry and material properties of an electrolyte-supported cell, different from those of the conventional cathode-supported cell ${ }^{1)}[8-10]$. Note that a total stack length of $0.4 \mathrm{~m}$ (in the $z$ direction) is assumed, comprising repeating individual cells in series, each of 50 $0.1 \mathrm{~m} \times 0.1 \mathrm{~m}$ (in the $x$ and $y$ directions). For this investigation, the inlet gas is kept as $90 \mathrm{~mol} \% \mathrm{H}_{2} \mathrm{O} / 10 \mathrm{~mol}^{\circ} \mathrm{H}_{2}$.

1) Cai Q, Luna-Ortiz E, Adjiman C S, Brandon N P. The effects of operating conditions on the performance of a solid oxide steam electrolyser: a model-based study. Submitted to Fuel Cells, 2010 
Table 2 Model input parameters and operating conditions

\begin{tabular}{|c|c|c|c|}
\hline input parameters & operating conditions & input parameters & operating conditions \\
\hline$h_{C} / \mathrm{m}$ & 0.001 & $c_{\mathrm{p}, \mathrm{s}} /\left(\mathrm{J} \cdot \mathrm{kg}^{-1} \cdot \mathrm{k}^{-1}\right)$ & 500 \\
\hline$h_{A} / \mathrm{m}$ & 0.001 & $c_{\mathrm{p}, \mathrm{I}} /\left(\mathrm{J} \cdot \mathrm{kg}^{-1} \cdot \mathrm{k}^{-1}\right)$ & 500 \\
\hline$h_{S} / \mathrm{m}$ & $2.15 \times 10^{-4}$ & $\lambda_{\mathrm{s}} /\left(\mathrm{J} \cdot \mathrm{m}^{-1} \cdot \mathrm{s}^{-1} \cdot \mathrm{K}^{-1}\right)$ & 2 \\
\hline$h_{I} / \mathrm{m}$ & $5.00 \times 10^{-4}$ & $\lambda_{\mathrm{I}} /\left(\mathrm{J} \cdot \mathrm{m}^{-1} \cdot \mathrm{s}^{-1} \cdot \mathrm{K}^{-1}\right)$ & 25 \\
\hline$L / \mathrm{m}$ & 0.4 & $\rho_{\mathrm{s}} / \mathrm{kg} \cdot \mathrm{m}^{-3}$ & 4873 \\
\hline$W / \mathrm{m}$ & 0.1 & $\rho_{\mathrm{I}} / \mathrm{kg} \cdot \mathrm{m}^{-3}$ & 7800 \\
\hline$\tau_{\text {cathode }} / \mathrm{m}$ & $5.5 \times 10^{-5}$ & $N u_{\mathrm{C}}$ & 3.68 \\
\hline$\tau_{\text {electrolyte }} / \mathrm{m}$ & $9.0 \times 10^{-5}$ & $N u_{\mathrm{A}}$ & 3.68 \\
\hline$\tau_{\text {anode }} / \mathrm{m}$ & $7.0 \times 10^{-5}$ & $\alpha$ & 0.5 \\
\hline$\sigma_{\text {cathode }} /\left(\Omega^{-1} \cdot \mathrm{m}^{-1}\right)$ & $1.0 \times 10^{5}$ & $T_{\mathrm{C}}^{0} / \mathrm{K}$ & 1073 \\
\hline$\sigma_{\text {electrolyte }} /\left(\Omega^{-1} \cdot \mathrm{m}^{-1}\right)$ & 1.9 & cathode stream inlet composition & $10 \mathrm{~mol} \% \mathrm{H}_{2} / 90 \mathrm{~mol}^{2} \mathrm{H}_{2} \mathrm{O}$ \\
\hline$\sigma_{\text {anode }} /\left(\Omega^{-1} \cdot \mathrm{m}^{-1}\right)$ & $1.0 \times 10^{4}$ & anode stream composition & $79 \mathrm{~mol} \% \mathrm{~N}_{2} / 21 \mathrm{~mol} \% \mathrm{O}_{2}$ \\
\hline$D_{\text {eff,cathode }} /\left(\mathrm{m}^{2} \cdot \mathrm{s}^{-1}\right)$ & $8.5 \times 10^{-5}$ & operating pressure/MPa & 0.1 \\
\hline$D_{\text {eff }, \text { anode }} /\left(\mathrm{m}^{2} \cdot \mathrm{s}^{-1}\right)$ & $14.5 \times 10^{-6}$ & $\begin{array}{l}\text { initial average current density } \\
/\left(\mathrm{A} \cdot \mathrm{cm}^{-2}\right)\end{array}$ & 1.0 \\
\hline$\varepsilon_{\mathrm{S}}$ & 0.4 & steam utilisation factor/\% & 80 \\
\hline$\varepsilon_{\mathrm{I}}$ & 0.7 & & \\
\hline
\end{tabular}

25 The addition of $10 \mathrm{~mol} \% \mathrm{H}_{2}$ in the cathode inlet stream is assumed sufficient to avoid the oxidation of the materials at elevated temperature. The steam utilisation factor, i.e. the percentage of the total inlet steam flow rate that is consumed by the reaction, must also be set. A higher steam

30 utilisation factor corresponds to a higher $\mathrm{H}_{2}$ production rate for a given amount of steam and is therefore desirable. However, it is also important for the steam utilisation factor to be low enough to avoid a significant increase in the cathode concentration overpotential caused by steam

35 starvation near the cell outlet. Here, a value of $80 \%$ is chosen. The stack is initially operating with an inlet cathode gas temperature of $1073 \mathrm{~K}$ and at an average current density of $1.0 \mathrm{~A} / \mathrm{cm}^{2}$. The effects of step changes in the average current density from $1.0 \mathrm{~A} / \mathrm{cm}^{2}$ to $0.75,0.5$ and

$40 \quad 0.2 \mathrm{~A} / \mathrm{cm}^{2}$ are investigated. The step change in the average current density is taken to happen instantly.

Steady-state simulations without air flow at the anode stream are first carried out to predict the cell potential and the temperature distribution in the stack under a range of 45 potential operating conditions, providing a base case for cell behaviour. The cell potentials at different current densities are shown in Fig. 2. It can be seen that the cell potential increases with increasing average current density at $1073 \mathrm{~K}$. The temperature distribution along the cathode

50 for cell operation at average current densities of 1.0, 0.75, 0.5 and $0.2 \mathrm{~A} / \mathrm{cm}^{2}$, maintaining all other conditions consistent with Table 1, are shown in Fig. 3. The inlet temperature is fixed at $1073 \mathrm{~K}$. Note that the cathode stream temperature changes rapidly after the cell entry,

55 reaching the temperature of other cell components within a very short distance of the inlet. While the temperature

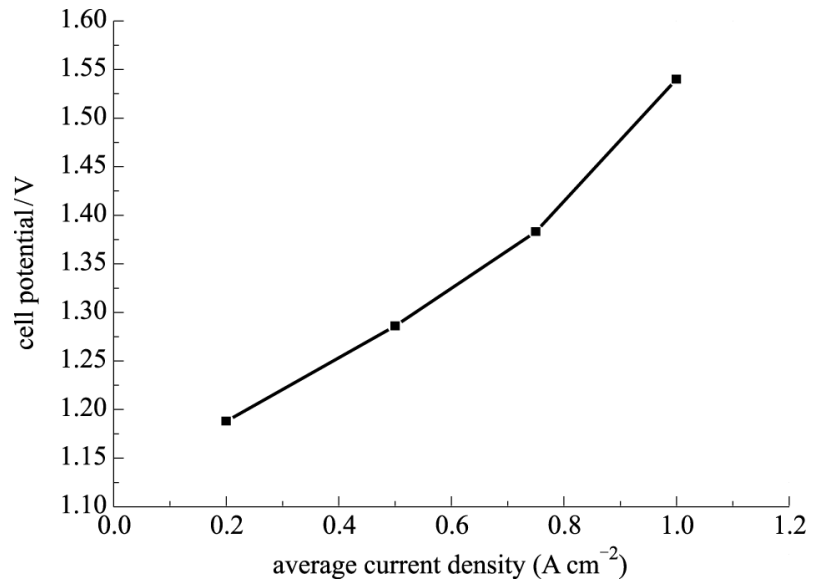

Fig. 2 Cell potential as a function of average current density at $1073 \mathrm{~K}$

increases along the cell at $1.0,0.75$ and $0.5 \mathrm{~A} / \mathrm{cm}^{2}$, featuring exothermic operation, the temperature decreases along the cell at $0.2 \mathrm{~A} / \mathrm{cm}^{2}$, featuring an endothermic operation. As can be seen in Fig. 3, the overall temperature gradient (i.e. the difference between the outlet temperature and the inlet temperature) depends significantly on the average current density; a temperature gradient of $479 \mathrm{~K}$ is found for operating at $1.0 \mathrm{~A} / \mathrm{cm}^{2}, 292 \mathrm{~K}$ for $0.75 \mathrm{~A} / \mathrm{cm}^{2}$, $120 \mathrm{~K}$ for $0.5 \mathrm{~A} / \mathrm{cm}^{2}$ and $50 \mathrm{~K}$ for $0.2 \mathrm{~A} / \mathrm{cm}^{2}$. Previous work has indicated that the maximum allowable total temperature difference along a $0.1 \mathrm{~m}$ cell is $100 \mathrm{~K}$ [11], otherwise the cell is at the risk of breakdown. As temperature gradients of above $100 \mathrm{~K}$ are observed along the $0.1 \mathrm{~m}$ cell at most of the investigated current densities, 
Fig. 3 Cathode stream temperature along the cell at different average current densities

strict cell temperature control is required to avoid significant thermal excursion.

The effect of feeding air on the anode side on the cell

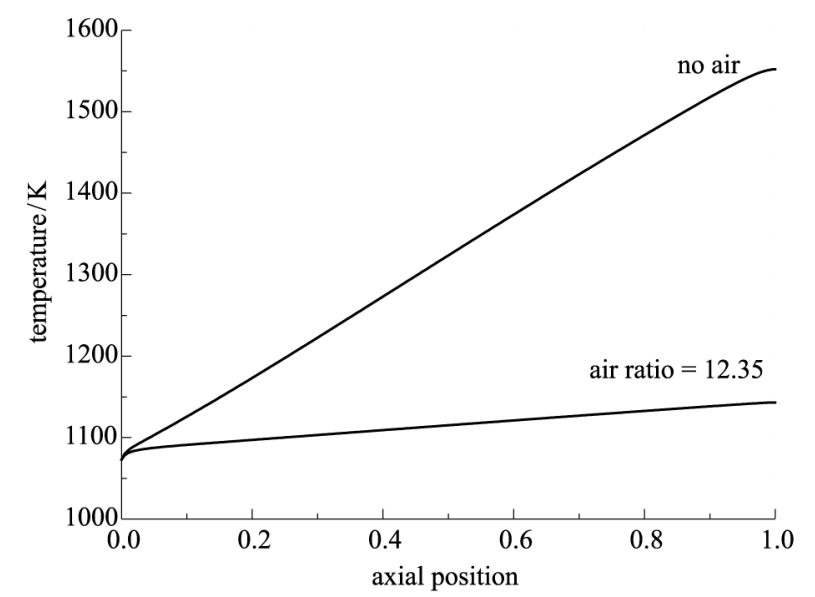

(a) temperature profiles is investigated in further steady-state simulations, using an appropriate air ratio. The air ratios required to maintain an acceptable overall temperature gradient for different average current densities are obtained. The cathode stream temperature profiles along the cell are shown in Fig. 4, comparing the two cases with and without air flow at the anode stream. As shown in Fig. 4(a)-(c), an air ratio of $12.35,5.92$ and 0.73 is used respectively for operating at $1.0,0.75$ and $0.5 \mathrm{~A} / \mathrm{cm}^{2}$ to keep the temperature gradient within acceptable limits. The air ratio is chosen for each case so as to obtain a temperature difference of $70 \mathrm{~K}$ between the inlet and the outlet, which is much lower than the maximum allowable total temperature difference of $100 \mathrm{~K}$. For the case of operating at $0.2 \mathrm{~A} / \mathrm{cm}^{2}$, there is no need to use air flow at the anode stream for temperature control as the absolute temperature difference between the inlet and the outlet is just $50 \mathrm{~K}$, as can be seen from Fig. 3. The stack is under endothermic operation in this case.

The stack is expected to have thermal excursions when changing the current density from its initial operating value of 1.0 to $0.75,0.5$ and $0.2 \mathrm{~A} / \mathrm{cm}^{2}$. Temperature control is

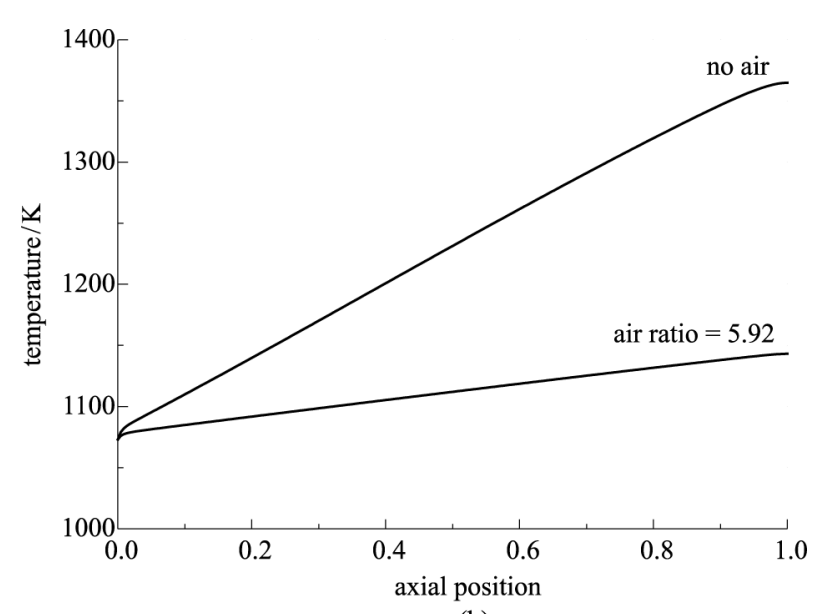

(b)

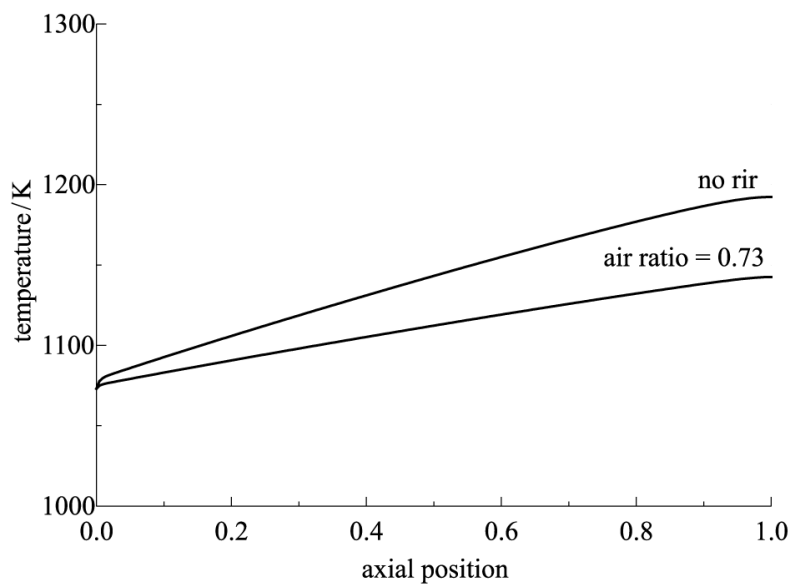

(c) 
1 thus required to maintain the temperature at its set-point and to minimise the temperature changes during a step change in the current density. The results of dynamic simulations are presented for the open-loop case in which 5 the stack temperature is left uncontrolled as well as for the closed-loop case in which an attempt has been made to provide temperature control. In the former, the air ratio is maintained constant at 12.35 , the air ratio used when operating at $1.0 \mathrm{~A} / \mathrm{cm}^{2}$, while in the latter, it is adjusted

10 progressively until it reaches the air ratio corresponding to the required steady-state air ratio at new current density, as shown in Fig. 4. The air ratio is changed linearly over a period of $100 \mathrm{~s}$, as illustrated in Fig. 5. Note that the change in air ratio is purposefully selected to be rather slow here

15 such that its effects on the stack temperature would clearly appear. As shown in Fig. 5, the air ratio is adjusted from 12.35 to 5.92 and 0.73 respectively when the current density is changed from 1.0 to 0.75 and $0.5 \mathrm{~A} / \mathrm{cm}^{2}$. It has been discussed before that there is no need for temperature 20 control when operating at $0.2 \mathrm{~A} / \mathrm{cm}^{2}$ as the absolute overall temperature gradient along the cell length is within the temperature gradient limit. Whereas, when the stack switches from operating at 1.0 to $0.2 \mathrm{~A} / \mathrm{cm}^{2}$, the stack is switching from the exothermic operation mode to the endothermic operation mode; the stack will go through a sudden temperature change across the stack. It is thus desirable to investigate the possibility of minimising the temperature change during such a step change in the average current density. The recommended maximum

30 value of air ratio (i.e.14) and other higher values have been used to see their effect on the temperature change. It is clear from our investigation that a sudden temperature drop still exists even with high air ratio values such as 17 , and it is impossible to change the operation from endothermic to

35 exothermic by manipulating air ratio. Furthermore, air ratio values higher than 14 have similar stack behaviour to that with an air ratio of 14 . Thus only the case of changing air ratio from 12.35 to 14 is shown for the step change in current density from 1.0 to $0.2 \mathrm{~A} / \mathrm{cm}^{2}$, as is seen in Fig. 6 .

40 The transient response of the cathode stream outlet temperature during step changes in the average current density is shown in Fig. 6, with and without air ratio manipulation. In Fig. 6, a rapid fall in the outlet temperature is observed soon (within 200 seconds) after

45 the step changes from 1.0 to $0.75,0.5$ and $0.2 \mathrm{~A} / \mathrm{cm}^{2}$, when there is no air ratio manipulation, i.e. when the air ratio is kept constant in spite of the step changes. The rapid fall of the temperature visible in Figs. 6 (a), (b) and (c) is attributed to the instantaneous change in the current

50 density. The decrease in the average current density causes a decrease in the heat generated via irreversible losses, reducing the stack temperature. The minimum outlet temperature of around 1116,1089 and $1055 \mathrm{~K}$ is reached following the step decrease in the average current density from 1.0 to $0.75,0.5$ and $0.2 \mathrm{~A} / \mathrm{cm}^{2}$ respectively, when there is no air ratio manipulation, i.e. when the air ratio is

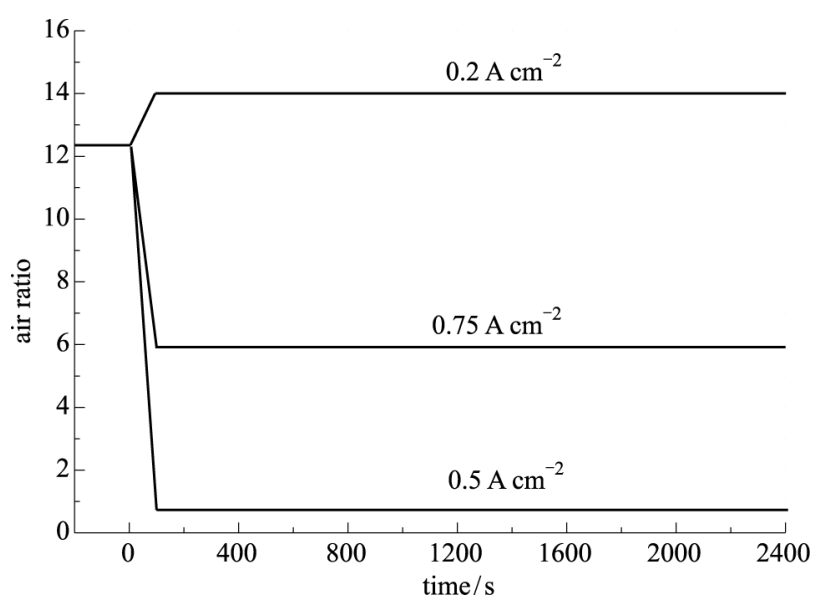

Fig. 5 Changes in the air ratio, applied to the stack in response to step changes in current density

kept at 12.35 which is the control value for $1.0 \mathrm{~A} / \mathrm{cm}^{2}$. The outlet temperature with air ratio manipulation in Figs. 6 (a) and (b) is characterised by moderate oscillations. Following the manipulation of the air ratio, the outlet temperature is eventually returned to its initial value after a decrease. After a negative step change in the average current density, the decrease in the air ratio results in decreased convective cooling of the stack, causing the stack temperature to rise back up to the initial value. When the average current density is changed from 1.0 to $0.75 \mathrm{~A} / \mathrm{cm}^{2}$, the outlet temperature takes 540 seconds ( 9 minutes) to return to the initial value, as shown in Fig. 6 (a); when the average current density is changed from 1.0 to $0.5 \mathrm{~A} / \mathrm{cm}^{2}$, a longer time (about 1800 seconds, i.e. 30 minutes) is required to stabilize the outlet temperature, as shown in Fig. 6 (b). When the average current density is changed from 1.0 to $0.2 \mathrm{~A} / \mathrm{cm}^{2}$, the outlet temperature can not be returned to its initial value, even with the air ratio being manipulated from its initial value of 12.35 to a maximum value of 14 , as shown in Fig. 6 (c). In this case, a minimum temperature of about $1057 \mathrm{~K}$ is reached after 490 seconds ( 7 minutes). The transient responses of the stack with air ratio manipulation are further compared in Fig. 7 for the three cases of switching the operating current density from 1.0 to 0.75 , 0.5 and $0.2 \mathrm{~A} / \mathrm{cm}^{2}$ respectively. It is clear that a small step change in the current density (e.g. from 1.0 to $0.75 \mathrm{~A} / \mathrm{cm}^{2}$ ) causes small temperature change and requires a short time to bring the temperature back to its initial value; a doubling in the decrease in the current density (e.g. by going from 1.0 to $0.5 \mathrm{~A} / \mathrm{cm}^{2}$ ) results in disproportionately large temperature change and time to bring the temperature back. When the step change in the current density is too big (e.g. from 1.0 to $0.2 \mathrm{~A} / \mathrm{cm}^{2}$ ) in which case the operating mode changes from exothermic to endothermic, the application of the temperature controller by manipulating air ratio at the anode side can not bring the temperature back. 


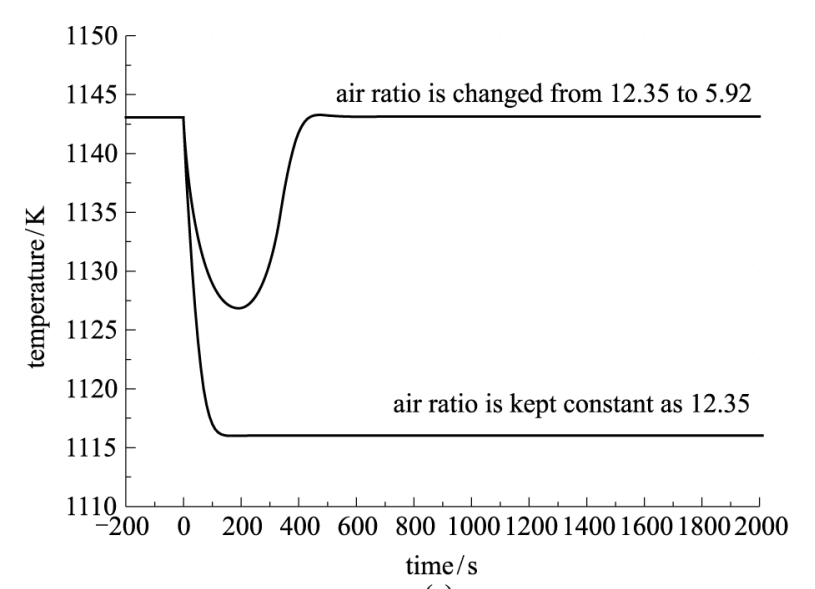

(a)

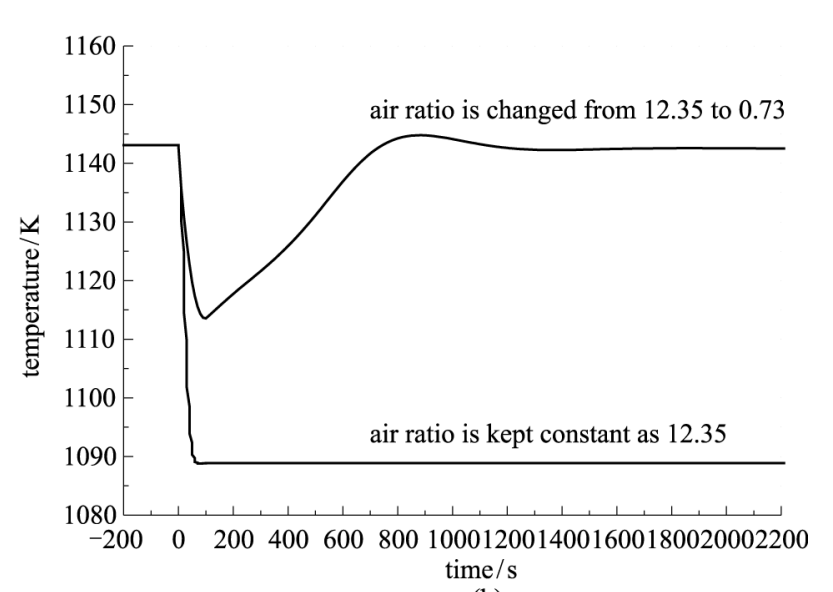

(b)
Fig. 6 Transient response of the cathode stream outlet temperature during step changes in current density (a) From 1.0 to $0.75 \mathrm{~A} / \mathrm{cm}^{2}$, (b) from 1.0 to $0.5 \mathrm{~A} / \mathrm{cm}^{2}$ and (c) from 1.0 to $0.2 \mathrm{~A} / \mathrm{cm}^{2}$

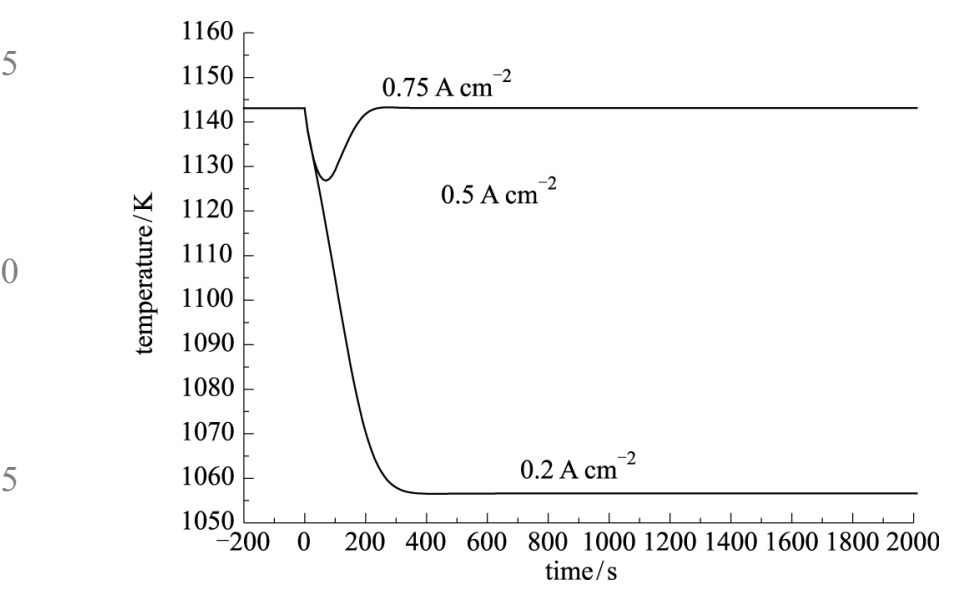

Fig. 7 Comparison of the transient response of the cathode stream outlet temperature

The transient response of the maximum localized temperature gradient in the solid structure for the imposed changes in the current density, in open- and closed cases (i. e. with and without air ratio manipulation), is presented in Figs. 8 and 9. In all the cases, the maximum localized solid structure temperature gradient is below $10 \mathrm{~K} / \mathrm{cm}$ which is the maximum allowed localized solid structure temperature gradient, indicating that the stack is under safe operation. A high maximum localized temperature gradient of $9.610 \mathrm{~K} / \mathrm{cm}$ is observed for operation at $1.0 \mathrm{~A} / \mathrm{cm}^{2}$, just below the limit condition of $10 \mathrm{~K} / \mathrm{cm}$. When the current density is decreased to $0.75,0.5$ and $0.2 \mathrm{~A} / \mathrm{cm}^{2}$, the observed maximum temperature gradient is lowered. For the cases with air ratio kept constant at 12.35 , as shown in Fig. 8, the maximum solid structure temperature gradient is observed to have some small oscillation and then reach 5.3, 1.6 and $1.1 \mathrm{~K} / \mathrm{cm}$ respectively for changes in the current 45 density from 1.0 to $0.75,0.5$ and $0.2 \mathrm{~A} / \mathrm{cm}^{2}$. For the cases with air ratio manipulation, as shown in Fig. 9, the maximum solid structure temperature gradient is observed to have small oscillation for changing the current density from 1.0 to 0.75 and $0.2 \mathrm{~A} / \mathrm{cm}^{2}$ but large oscillations for 50 changing the current density from 1.0 to $0.5 \mathrm{~A} / \mathrm{cm}^{2}$; the stabilized maximum solid structure temperature gradient is observed to be $5.1,3.5$ and $1.0 \mathrm{~K} / \mathrm{cm}$ respectively for changing the current density from 1.0 to $0.75,0.5$ and $0.2 \mathrm{~A} / \mathrm{cm}^{2}$.

The transient response of the cell potential during step 55 changes in the average current density, imposed with and 


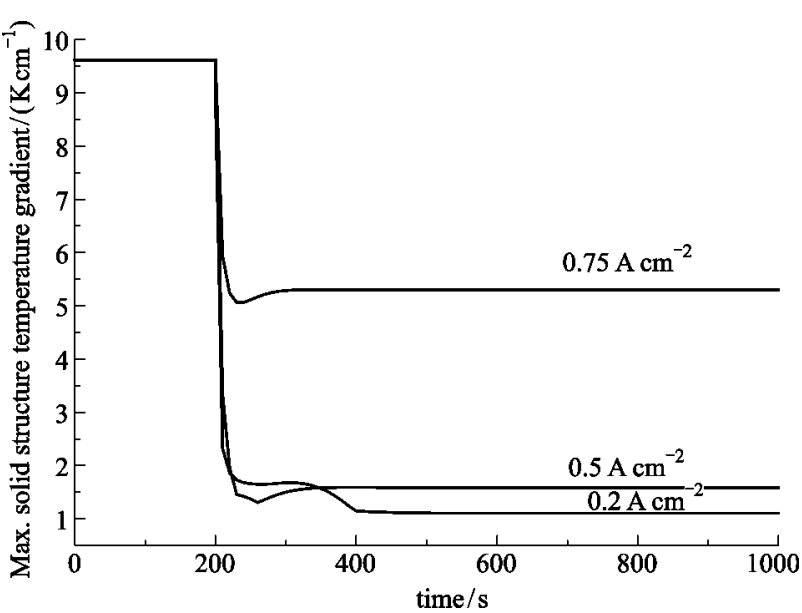

Fig. 8 Transient response of the maximum localized solid structure temperature gradient in open-loop cases

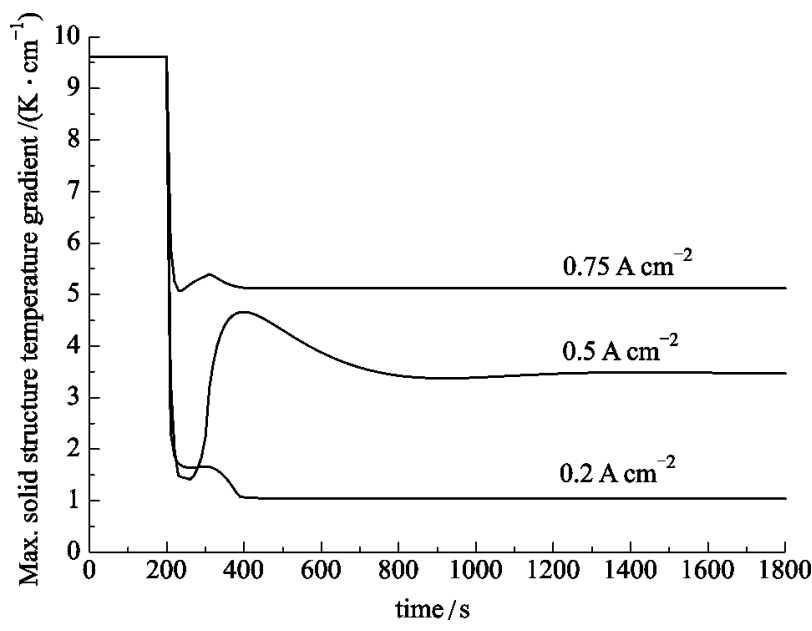

Fig. 9 Transient response of the maximum solid structure temperature gradient in closed-loop cases

without air ratio manipulation, is shown in Figs. 10 and 11. 40 During a negative step change, the cell potential is instantaneously decreased due to an immediate fall in irreversible losses. The stack temperature, on the other hand, is reduced over a greater time interval as shown in Fig. 6 . Such a reduction in the stack temperature causes the 45 irreversible losses to progressively rise, increasing the cell potential until the final steady state is reached. Without air ratio manipulation, the negative step change to $0.75,0.5$ and $0.2 \mathrm{~A} / \mathrm{cm}^{2}$ leads to minimum cell potentials of around $1.47,1.32$ and $1.11 \mathrm{~V}$ respectively, as shown in Fig. 10; in

50 the cases with air ratio manipulation, the step change to $0.75,0.5$ and $0.2 \mathrm{~A} / \mathrm{cm}^{2}$ causes minimum cell potentials of around $1.45,1.29$ and $1.108 \mathrm{~V}$ respectively, as shown in Fig. 11. Compared to the cell potentials predicted by the steady state simulations in which there is no air flow in the

55 anode stream, the cell potentials shown in Figs. 10 and 11 are higher for $1.0,0.75$ and $0.5 \mathrm{~A} / \mathrm{cm}^{2}$, but lower for

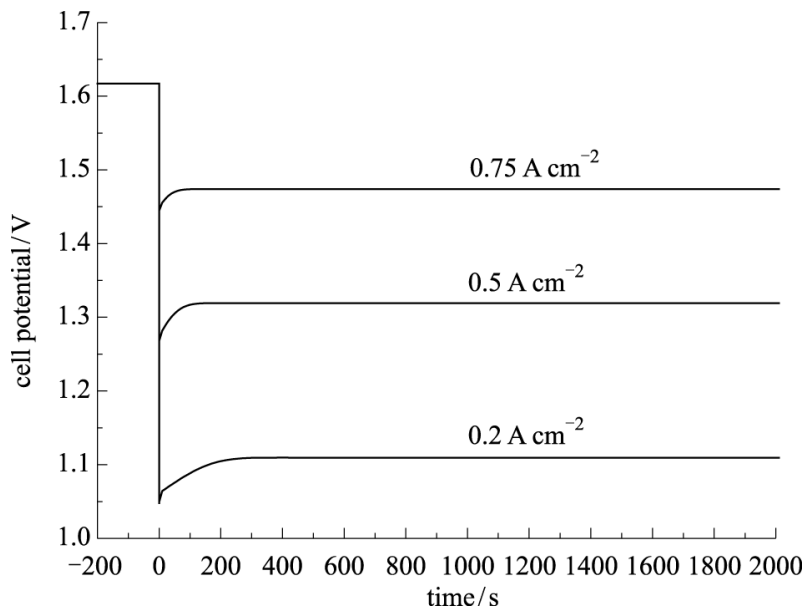

Fig. 10 Transient response of the cell potential in open-loop cases

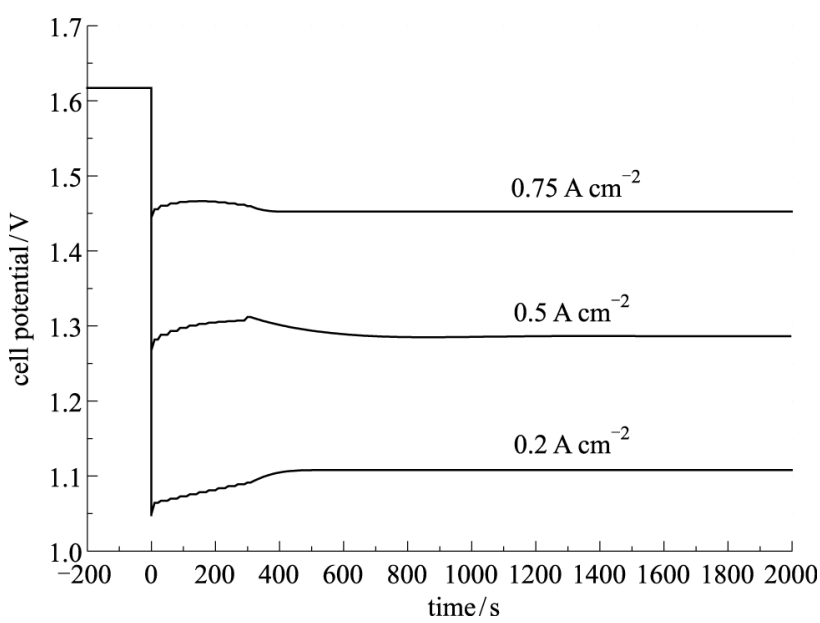

Fig. 11 Transient response of the cell potential in closed-loop cases

$0.2 \mathrm{~A} / \mathrm{cm}^{2}$. This is mainly due to the effect of temperature control. With air flow in the anode stream, the temperatures are reduced in the cases of operation at 1.0, 0.75 and $0.5 \mathrm{~A} / \mathrm{cm}^{2}$, but increased in the case of operation at $0.2 \mathrm{~A} / \mathrm{cm}^{2}$. Thus the cell potential is increased and decreased accordingly.

It takes up to 300 seconds for the cell potential to stabilize itself in the cases without air ratio manipulation; a longer time of around 600 seconds is needed for the cases with air ratio manipulation. The differences between Figs. 10 and 11 are mainly attributed to the differences in the temperature profiles. As shown in Fig. 6, upon the change of the current density from 1.0 to $0.75,0.5$ and $0.2 \mathrm{~A} / \mathrm{cm}^{2}$, the outlet temperatures are higher in the cases with air ratio manipulation than those without air ratio manipulation. On the other hand, the temperature profiles in the cases with air ratio manipulation are characterised by oscillations and a longer period of stabilization. Thus the cell potentials in Fig. 11 are marginally lower and take a longer time to stabilize, compared to those in Fig. 10. 


\section{Conclusions}

A one-dimensional dynamic model of a planar SOEC stack has been employed to study the dynamic behaviour of such an SOEC and the prospect for stack temperature control through variation of the air flow rate. Step changes in the average current density are imposed to the stacks, replicating the situation in which the changes in the supply of input electrical energy are experienced, for example from a renewable supply, or the sudden switch-off of the stack. Such simulations have been performed both with and without the manipulation of the air ratio, providing some insight into the potential for temperature control.

The stack temperature and cell voltage are altered by the 15 step changes in the average current density. Without the variation of the air flow rate, a sudden fall in temperature (within 200 seconds) is observed during all the step changes in the average current density. The interim temperature excursions between the initial and final steady states are observed to be reduced by the introduction of air ratio changes. The use of the air ratio as a control variable ensures the maximum overall temperature gradient and the maximum localized temperature gradient in the solid structure remain within acceptable bounds for some small to medium changes in the average current density, but not for large changes. The smaller step changes in the average current density are more easily handled in that a considerably shorter time is required to return to the initial temperature. For example, for a step change from 1.0 to $0.75 \mathrm{~A} / \mathrm{cm}^{2}$, the stack takes 9 minutes to adjust the temperature back to its initial temperature; whilst for a step change from 1.0 to $0.5 \mathrm{~A} / \mathrm{cm}^{2}$, the stack takes 30 minutes to do the temperature adjustment. When the step change in the average current density is too big (e.g. from 1.0 to $0.2 \mathrm{~A} / \mathrm{cm}^{2}$ ), altering the stack from a typical exothermic mode to an endothermic mode, a large drop in the temperature occurs and a simple manipulation of the air ratio is insufficient to bring the temperature back to its initial value. Note that the stack goes through a temperature drop of around $88 \mathrm{~K}$ over the period of 300 seconds, when the current density is decreased suddenly from 1.0 to $0.2 \mathrm{~A} / \mathrm{cm}^{2}$ in both cases with and without air ratio manipulation, as shown in Fig. 6. If the stack could survive the temperature drop of $88 \mathrm{~K}$ over the period of 300 seconds, such shut-down may not be destructive to the stack, given that the maximum solid structure temperature gradient is small and stabilizes at $1.0 \mathrm{~K} / \mathrm{cm}$. The control of stack temperature is observed to decrease the difference between the cell potential at the initial steady state and that at the final steady state, compared to the case without the control. The cell potential transitions take a longer time to reach the final steady state when a temperature controller via the variation of the air flow rate is employed.

Acknowledgements This work was supported by the seventh framework of European Commission under the project RELHY ("Innovative solid oxide electrolyser stacks for efficient and reliable hydrogen production") (Grant No. 213009).

\section{Notation}
$c_{\mathrm{p}, \mathrm{C}}, c_{\mathrm{p}, \mathrm{A}}, c_{\mathrm{p}, \mathrm{S}}, c_{\mathrm{p}, \mathrm{I}}$
heat capacity of the cathode and anode gas streams, solid structure and interconnect $/\left(\mathrm{J} \cdot \mathrm{kg}^{-1} \cdot \mathrm{K}^{-1}\right)$
$C_{\mathrm{H}_{2}}, C_{\mathrm{H}_{2} \mathrm{O}}, C_{\mathrm{O}_{2}}, C_{\mathrm{N}_{2}}$
concentration of hydrogen, steam, oxygen and nitrogen in the cathode and anode gas streams $/\left(\mathrm{mol} \cdot \mathrm{m}^{-3}\right)$
$C_{i}$
concentration of gas species $i$ in the cathode and
$C_{i}^{0}$ anode gas streams $/\left(\mathrm{mol} \cdot \mathrm{m}^{-3}\right)$
$C_{\mathrm{H}_{2}}^{\mathrm{TPB}}, C_{\mathrm{H}_{2} \mathrm{O}}^{\mathrm{TPB}}, C_{\mathrm{O}_{2}}^{\mathrm{TPB}}$
concentration of gas species $i$ at the cell inlet $/\left(\mathrm{mol} \cdot \mathrm{m}^{-3}\right)$
$d_{\mathrm{h}, \mathrm{C}}, d_{\mathrm{h}, \mathrm{A}}$
concentration of hydrogen, steam and oxygen at the triple phase boundary $/\left(\mathrm{mol} \cdot \mathrm{m}^{-3}\right)$
$D_{\text {eff,cathode }}, D_{\text {eff,anode }}$
hydraulic diameter of the cathode and anode gas channels $/ \mathrm{m}$
average effective diffusivity coefficient of the cathode and anode $/\left(\mathrm{m}^{2} \cdot \mathrm{s}^{-1}\right)$
$E_{\text {cathode }}, E_{\text {anode }}$
activation energy for the exchange current density of the cathode and anode $/\left(\mathrm{J} \cdot \mathrm{mol}^{-1}\right)$
$E_{\text {electrode }}$
activation energy for the exchange current density of an electrode $/\left(\mathrm{J} \cdot \mathrm{mol}^{-1}\right)$$$
h_{\mathrm{C}}, h_{\mathrm{A}}, h_{\mathrm{S}}, h_{\mathrm{I}}
$$
$j_{0, \text { cathode }}, j_{0, \text { anode }}$
inlet flow rate of the anode streams $/\left(\mathrm{mol} \cdot \mathrm{s}^{-1}\right)$
Faraday's constant $/\left(\mathrm{C} \cdot \mathrm{mol}^{-1}\right)$
height of the cathode and anode channels, and thickness of the solid structure and interconnect $/ \mathrm{m}$ local current density $/\left(\mathrm{A} \cdot \mathrm{m}^{-2}\right)$
exchange current density of the cathode and anode $/\left(\mathrm{A} \cdot \mathrm{m}^{-2}\right)$

$J_{\mathrm{A}}$$$
\text { F }
$$

\section{$j$}

$j_{0, \text { electrode }}$

$\bar{j}$

$k_{\mathrm{C}}, k_{\mathrm{A}}$

$k_{\text {cathode }}, k_{\text {anode }}$

\section{$k_{\text {electrode }}$}

L

$N u_{\mathrm{C}}, N u_{\mathrm{A}}$

\section{$P_{\mathrm{O}_{2}}$}

$P_{\mathrm{O}_{2}}^{\mathrm{TPB}}$

R

$R_{\mathrm{Ohm}}$

$\Re$

$t$

$T$

$T_{\mathrm{C}}, T_{\mathrm{A}}, T_{\mathrm{S}}, T_{\mathrm{I}}$ exchange current density of an electrode $/\left(\mathrm{A} \cdot \mathrm{m}^{-2}\right)$ Average current density of an electrode $/\left(\mathrm{A} \cdot \mathrm{m}^{-2}\right)$

convective heat transfer coefficient between the solid parts of the cell and the cathode and anode gas streams $/\left(\mathrm{J} \cdot \mathrm{m}^{-2} \cdot \mathrm{s}^{-1} \cdot \mathrm{K}^{-1}\right)$

pre-exponential factor for the exchange current density of the cathode and anode $/\left(\Omega^{-1} \cdot \mathrm{m}^{-2}\right)$

pre-exponential factor for the exchange current density of an electrode $/\left(\Omega^{-1} \cdot \mathrm{m}^{-2}\right)$

cell length/m

Nusselt number of the cathode and anode gas streams

oxygen pressure in the anode gas stream $/ \mathrm{Pa}$ oxygen pressure at the triple phase boundary $/ \mathrm{Pa}$ reaction rate $\left(\mathrm{mol} \cdot \mathrm{s}^{-1} \cdot \mathrm{m}^{-2}\right)$

total resistance of the cell including electric and ionic resistances $/\left(\Omega \cdot \mathrm{m}^{2}\right)$

gas constant $\left(\mathrm{J} \cdot \mathrm{mol}^{-1} \cdot \mathrm{K}^{-1}\right)$

Time/s

temperature/K

temperature of the cathode and anode gas streams, solid structure and interconnect $/ \mathrm{K}$ 
1

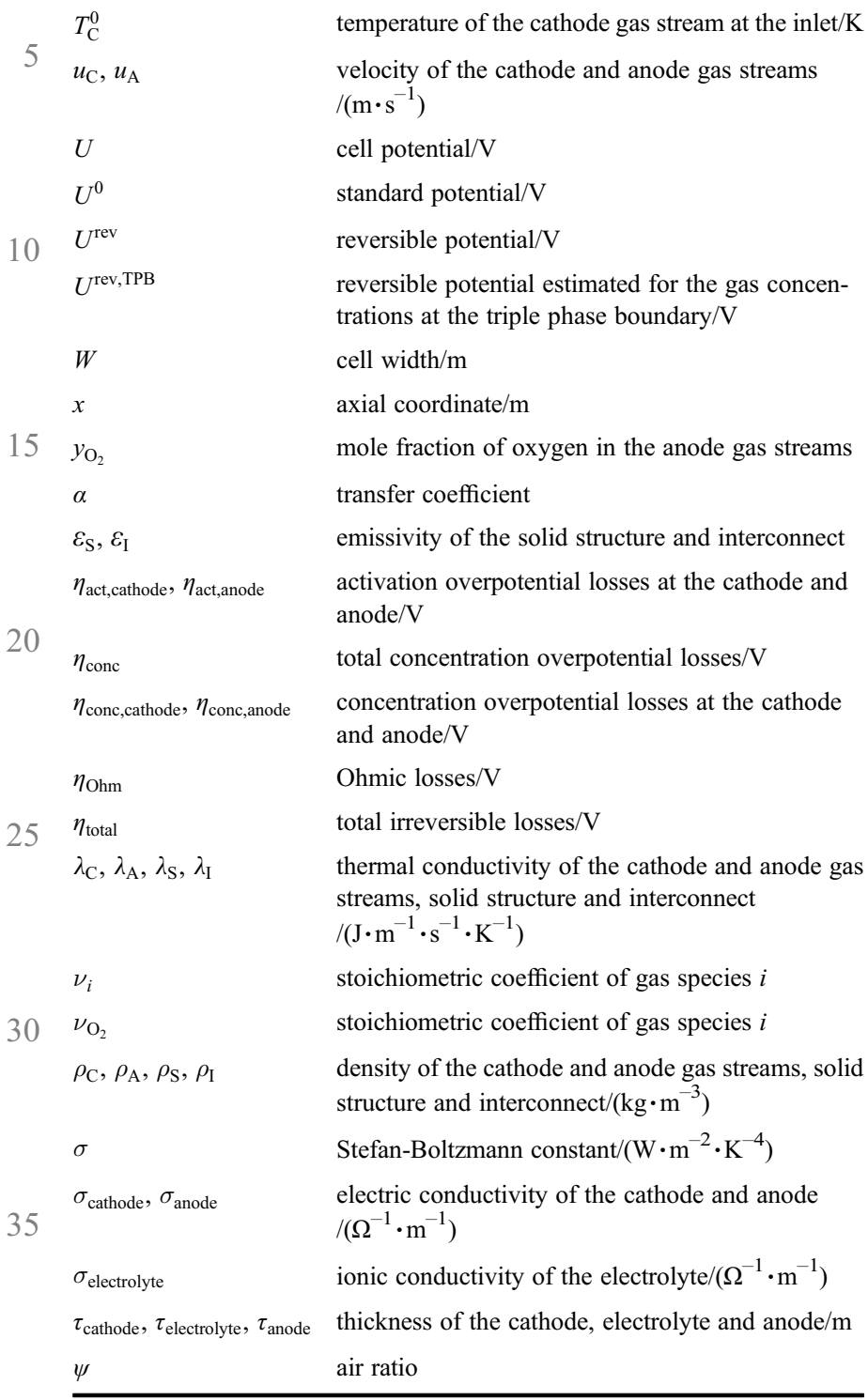

40
(Continued)

heat capacity of the cathode and anode gas streams, solid structure and interconnect $/\left(\mathrm{J} \cdot \mathrm{kg}^{-1} \cdot \mathrm{K}^{-1}\right)$ temperature of the cathode gas stream at the inlet $/ \mathrm{K}$ velocity of the cathode and anode gas streams $/\left(\mathrm{m} \cdot \mathrm{s}^{-1}\right)$

cell potential/ $\mathrm{V}$

reversible potential estimated for the gas concenat the triple phase boundary/

axial coordinate $/ \mathrm{m}$

emissivity of the solid structure and interconnect

activation overpotential losses at the cathode and

concentration overpotential losses at the cathode

total irreversible losses/V

streams, solid structure and interconnect

$\mathrm{m}^{-1} \cdot \mathrm{s} \cdot \mathrm{K}^{-1}$

stoichiometric coefficient of gas species

density of the cathode and anode gas streams, solid structure and interconnect $/\left(\mathrm{kg} \cdot \mathrm{m}^{-3}\right)$

lectric conductivity of the cathode and anode $/\left(\Omega^{-1} \cdot \mathrm{m}^{-1}\right)$

air ratio

\section{References}

1. Liu Mingyi, Yu Bo, Xu Jingming, Chen Jing. Thermodynamic analysis of the efficiency of high-temperature steam electrolysis system for hydrogen production. Journal of Power Sources, 2008, 177(2): 493-499

2. Stojic D L, Marceta M P, Sovilj S P, Miljanic S S. Hydrogen generation from water electrolysis-possibilities of energy saving. Journal of Power Sources, 2003, 118 (1-2): 315-319

3. Padina J, Veziroglu T N, Shahin A. Hybrid solar high-temperature hydrogen production system. International Journal of Hydrogen Energy, 2000, 25(4): 295-317

4. Jensen S H, Larsen P H, Mogensen M. Hydrogen and synthetic fuel production from renewable energy sources. International Journal of Hydrogen Energy, 2007, 32(15): 3253-3257

5. Sigurvinsson J, Mansilla C, Arnason B. Heat transfer problems for the production of hydrogen from geothermal energy. Energy Conversion and Management, 2006, 47(20): 3543-3551

6. Sigurvinsson J, Mansilla C, Lovera P, Werkoffa F. Can high temperature steam electrolysis function with geothermal heat? International Journal of Hydrogen Energy, 2007, 32(9): 1174-1182

7. Elder R, Allen R. Nuclear heat for hydrogen production: Coupling a very high/high temperature reactor to a hydrogen production plant. Progress in Nuclear Energy, 2009, 51(3): 500-525

8. Udagawa J, Aguiar P, Brandon N P. Hydrogen production through steam electrolysis: Model-based steady state performance of a cathode-supported intermediate temperature solid oxide electrolysis cell. Journal of Power Sources, 2007, 166(1): 127-136

9. Udagawa J, Aguiar P, Brandon N P. Hydrogen production through steam electrolysis: Model-based dynamic behaviour of a cathodesupported intermediate temperature solid oxide electrolysis cell. Journal of Power Sources, 2008, 180(1): 46-55

10. Udagawa J, Aguiar P, Brandon N P. Hydrogen production through steam electrolysis: Control strategies for a cathode-supported intermediate temperature solid oxide electrolysis cell. Journal of Power Sources, 2008, 180(1): 354-364

11. Aguiar P, Adjiman CS, Brandon N P. Anode-supported intermediate-temperature direct internal reforming solid oxide fuel cell: Model-based dynamic performance and control. Journal of Power Sources, 2005, 147(1-2): 136-147 